\title{
PENERAPAN METODE MAKE A MATCH DALAM UPAYA MENINGKATKAN MOTIVASI DAN HASIL BELAJAR FISIKA MATERI GELOMBANG BUNYI PADA SISWA KELAS XII IPA 4 SMA NEGERI 1 TEBING TINGGI T.A 2014/2015
}

\author{
ABSTRAK \\ Nelfiza \\ Email : nelfiza66@gmail.com
}

Permasalahan dalam penelitian ini adalah rendahnya hasil belajar dan kurangnya keaktifan siswa pada mata pelajaran fisika di Kelas XII IPA 4 SMA Negeri 1 Tebing Tinggi. Penelitian ini bertujuan untuk meningkatkan hasil belajar dan keaktifan siswa dalam proses pembelajaran pada aspek kognitif pada materi mendeskripsikan gelombang bunyi. Metode pembelajaran yang dipakai dalam penelitian ini adalah metode Make a Match. Jenis penelitian yang dilakukan adalah penelitian tindakan kelas (classroom action research) dan dilaksanakan selama dua siklus. Setiap siklus terdiri dari 4 tahap yaitu perencanaan, tindakan, pengamatan dan refleksi/evaluasi. Instrumen penelitian menggunakan lembar pengamatan pelaksanaan pembelajaran dengan metode Make a Match. Subjek dalam penelitian ini adalah siswa Kelas XII IPA 4 SMA Negeri 1 Tebing Tinggi Tahun Ajaran 2014/2015 dengan jumlah siswa 32 orang. Penentuan subjek diperoleh berdasarkan hasil investigasi terhadap kelas yang akan diteliti dan berdasarkan hasil rujukan dari Kepala Sekolah. Pada siklus I pertemuan I diperoleh data tidak ada siswa yang mempunyai motivasi belajar sangat baik, 3 orang siswa yang tergolong baik, 20 orang siswa yang tergolong cukup, dan 9 orang siswa yang tergolong kurang. Pada siklus I pertemuan II, motivasi belajar siswa masih rendah walaupun telah mengalami peningkatan dari pertemuan sebelumnya. Terdapat siswa yang mempunyai motivasi belajar siswa yang tergolong baik dan cukup. Pada siklus I pertemuan II diperoleh data bahwa tidak ada siswa yang memperoleh kriteria sangat baik, 10 orang siswa yang tergolong baik, 22 orang siswa yang tergolong cukup, dan tidak ada siswa yang tergolong kurang. Pada siklus II pertemuan I diperoleh data bahwa 2 orang siswa yang tergolong sangat baik, 23 orang siswa tergolong baik, 7 orang siswa tergolong cukup dan tidak ada siswa yang tergolong kurang. Pada siklus II pertemuan II diperoleh data bahwa 4 orang siswa tergolong sangat baik, 26 orang tergolong baik, 2 orang tergolong cukup, dan tidak ada siswa yang tergolong kurang. Pada pelaksanaan tindakan pada siklus II pertemuan II sudah mendapatkan hasil yang lebih baik mencapai kriteria yang diharapkan. Hal ini di buktikan dari nilai ratarata yang diperoleh siswa pada siklus II pertemuan ke II, yaitu 78,7. Dengan tercapainya tingkat ketuntasan pada siklus II, maka proses belajar mengajar tidak lagi dilanjutkan pada siklus berikutnya.

Kata kunci : metode pembelajaran Make a Match., motivasi, hasil belajar fisika.

\begin{abstract}
ABSTRCT
The problem of this research is in this study are the low yields and the lack of involvement of the student learning in physics in Class XII IPA 4 SMA Negeri 1 Tebing Tinggi. This study
\end{abstract}


aims to improve student learning outcomes and student activity and play an active role in the learning process on a cognitive aspect of material describing the wave. The learning method used in this research is the method Make a Match.Type of research is the Classroom Action Research (Classroom Action Research) and held for two cycles. Each cycle consists of four stages: planning, action, observation and reflection/evaluation. The research instrument used observation sheet implementation of learning methods Make a Match. Subjects in this study were students of Class XII IPA 4 SMA Negeri 1 Tebing Tinggi school year of 2014/2015 with the number of students 32 people. Determination of the subject obtained based on the investigation of a class that will be researched and based on the result of referrals from the Principal. In the first cycle of data gathering I obtained no student who has the motivation to learn is very good, three students were classified as good, 20 students were classified as adequate, and 9 students were classified as less. In the first cycle II meeting, student motivation is still low despite increased from the previous meeting. There are students with students' motivation is quite good and fairly. In the first cycle of meetings II data showed that no students who obtain excellent criteria, 10 students were classified as good, 22 students classified as sufficient, and no student is classified as less. At the first meeting of the second cycle data showed that two students were classified as very good, 23 students classified as excellent, 7 students is quite and no student is classified as less. In the second cycle II meeting data showed that four students classified as very good, 26 are classified as good, 2 quite enough, and no student is classified as less. On the implementation of the action on the second cycle II meeting has been getting better results achieve the expected criteria. It is proved from the average value obtained by the students in the second cycle to the second meeting, which is 78.7. With the achievement of mastery level in the second cycle, the learning process has been discontinued in the next cycle.

Key Words : Make a Match learning method, motivation, learning physics.

\section{PENDAHULUAN}

Keberhasilan belajar siswa dapat ditentukan oleh motivasi belajar yang dimilikinya. Siswa yang memiliki motivasi belajar tinggi cenderung prestasinyapun akan tinggi pula, sebaliknya siswa yang motivasi belajarnya rendah, akan rendah pula prestasi belajarnya. Hal ini sejalan dengan pendapat Hawley (dalam Uno, 2008:191) yang menyatakan bahwa para siswa yang memiliki motivasi tinggi, belajarnya lebih baik dibandingkan dengan para siswa yang motivasinya rendah. Hal ini disebabkan karena motivasi merupakan penggerak atau pendorong untuk melakukan tindakan tertentu. Tinggi rendahnya motivasi dapat menentukan hasil yang diperoleh. Dalam proses pembelajaran motivasi merupakan salah satu aspek dinamis yang sangat penting. Sering terjadi siswa yang kurang berprestasi bukan disebabkan oleh kemampuannya yang kurang, akan tetapi dikarenakan tidak adanya motivasi untuk belajar sehingga siswa tidak berusaha untuk menggerakkan segala kemampuannya.

Sardiman (2009:73) menyatakan bahwa motif adalah daya upaya yang mendorong seseorang untuk melakukan sesuatu. Motif dapat dikatakan sebagai daya penggerak dari dalam diri dan di dalam subjek untuk melakukan aktivitasaktivitas tertentu demi mencapai suatu tujuan. Motif juga dapat diartikan sebagai suatu kondisi intern (kesiap-siagaan) sedangkan motivasi diartikan sebagai daya penggerak yang telah menjadi aktif.

Dalam proses pembelajaran tradisional yang menggunakan ekspositori sebagai strategi pembelajaran utama, terkadang unsur motivasi ini terlupakan guru. Guru sering memaksakan agar siswa menerima materi pelajaran yang disampaikannya. Pentingnya materi pelajaran yang diberikan sering hanya dipandang dari sudut guru, bukan dari 
sudut siswa sebagai subjek belajar. Akibatnya, siswa belajar seadanya tanpa motivasi. Cara yang demikian tentu sangat tidak menguntungkan, sebab siswa belajar tidak akan optimal yang berarti pencapaian tujuan pembelajaran pun tidak akan optimal pula. Oleh sebab itu, sebagai seorang profesional, seorang guru harus mempunyai pengetahuan dan persediaan metode-metode belajar. Guru memiliki pengaruh besar terhadap motivasi belajar siswa, karena itu guru harus menjadi idola bagi peserta didik sebab ada kecenderungan jika siswa menyukai guru yang mengajar mereka, maka motivasi belajar siswa akan lebih baik. Guru hendaknya berusaha agar siswa senang berinteraksi dengan baik saat pembelajaran berlangsung.

Dalam hal ini, perlu dirancang suatu pembelajaran yang membiasakan siswa untuk mengkonstruksi sendiri pengetahuannya, sehingga siswa lebih memahami konsep yang diajarkan mampu mengkomunikasikan pemikirannya baik dalam bentuk lisan maupun tulisan.

$\begin{array}{cccc}\text { Salah satu cara yang dapat } \\ \text { dilakukan } & \text { untuk } & \text { meningkatkan }\end{array}$ pemahaman konsep dan kemampuan komunikasi fisika siswa adalah dengan melaksanakan strategi pembelajaran yang relevan untuk diterapkan oleh guru. Strategi pembelajaran yang sebaiknya diterapkan adalah strategi pembelajaran yang memberikan kesempatan kepada siswa untuk mengkonstruksi pengetahuannya sendiri sehingga siswa lebih mudah untuk memahami konsep yang diajarkan dan mengkomunikasikan ide-idenya dalam bentuk lisan maupun tulisan.

\section{Menurut Mc.Donald (dalam} Sardiman, 2009:73), motivasi adalah perubahan energi dalam diri seseorang yang ditandai dengan munculnya "feeling" dan didahului dengan tanggapan terhadap adanya tujuan. Dari pengertian yang dikemukakan oleh Mc.Donald ini mengandung tiga elemen/ciri pokok dalam motivasi itu, yakni motivasi itu mengawali terjadinya perubahan energi, ditandai dengan adanya feeling dan dirangsang karena adanya tujuan.

Motivasi dan belajar merupakan dua hal yang saling mempengaruhi. Belajar adalah perubahan tingkah laku secara relatif permanen dan secara potensial terjadi sebagai hasil dari praktik penguatan (motivasi) yang dilandasi tujuan untuk mencapai tujuan tertentu (Slameto. 2010).

Djamarah dan Zain (2006:10) "belajar adalah proses perubahan perilaku berkat pengalaman dan latihan”. Artinya tujuan kegiatan adalah perubahan tingkah laku baik yang menyangkut pengetahuan, keterampilan maupun sikap, bahkan meliputi segenap aspek organisme dan pribadi.

Motivasi belajar dapat timbul karena faktor intrinsik, berupa hasrat dan keinginan berhasil dan dorongan kebutuhan belajar, harapan akan cita-cita. Faktor ekstrinsiknya adalah adanya penghargaan, lingkungan belajar yang kondusif, dan kegiatan belajar yang menarik. Tetapi harus diingat, kedua faktor tersebut disebabkan oleh rangsangan tertentu, sehingga seseorang berkeinginan untuk melakukan aktivitas belajar yang lebih giat dan semangat.

Model pembelajaran cooperative learning belum banyak diterapkan dalam pendidikan walaupun orang Indonesia sangat membanggakan sifat gotong royong dalam kehidupan bermasyarakat. Kebanyakan pengajar enggan menerapkan sistem kerja sama di dalam kelas karena beberapa alasan. Alasan yang utama adalah kekhawatiran bahwa akan terjadi kekacauan di kelas dan siswa tidak belajar jika mereka ditempatkan dalam grup. Selain itu, banyak orang mempunyai kesan negatif mengenai kegiatan kerja sama atau belajar dalam kelompok. Banyak siswa juga tidak senang disuruh bekerja sama dengan yang lain. Siswa yang tekun merasa harus bekerja melebihi siswa yang lain dalam grup mereka, sedangkan siswa yang kurang mampu merasa minder 
ditempatkan dalam satu grup dengan siswa yang lebih pandai. Siswa yang tekun juga merasa temannya yang kurang mampu hanya menumpang saja pada hasil jerih payah mereka.

Model pembelajaran cooperative learning tidak sama dengan sekedar belajar dalam kelompok. Ada unsur-unsur dasar pembelajaran cooperative learning yang membedakannya dengan pembagian kelompok yang dilakukan asal-asalan. Pelaksanaan prosedur model cooperative learning dengan benar akan memungkinkan pendidik mengelola kelas dengan lebih efektif.

Metode pembelajaran Make a Match artinya model pembelajaran mencari pasangan. Suasana pembelajaran dalam metode pembelajaran make a match akan riuh, tetapi sangat asik dan menyenangkan. Metode make a match atau mencari pasangan merupakan salah satu alternatif yang dapat diterapkan kepada siswa. Penerapan metode ini dimulai dari teknik yaitu siswa disuruh mencari pasangan kartu yang merupakan jawaban/soal sebelum batas waktunya, siswa yang dapat mencocokkan kartunya diberi poin.

match $\begin{array}{rc}\text { Metode } & \text { pembelajaran make a } \\ \text { atau mencari } & \text { pasangan }\end{array}$ dikembangkan oleh Lorna Curran (dalam Lie, 2010:55) mengatakan bahwa salah satu keunggulan tehnik ini adalah siswa mencari pasangan sambil belajar mengenai suatu konsep atau topik dalam suasana yang menyenangkan. Teknik ini bisa digunakan dalam semua mata pelajaran dan untuk semua tingkatan usia anak didik. Metode make a match memberikan manfaat bagi siswa, diantaranya sebagai berikut: (1) Mampu menciptakan suasana belajar aktif dan menyenangkan .(2) Materi pembelajaran yang disampaikan lebih menarik perhatian siswa.(3) Mampu meningkatkan motivasi belajar siswa.

Pada penerapan metode make a match dapat memupuk kerja sama siswa dalam menjawab pertanyaan dengan mencocokan kartu yang ada di tangan mereka, proses pembelajaran lebih menarik dan nampak sebagian besar siswa lebih antusias mengikuti proses pembelajaran, dan keaktifan siswa tampak sekali pada saat siswa mencari pasangan kartunya masing-masing.

Siswa yang termotivasi dalam belajarnya dapat dilihat dari karakteristik tingkah laku yang menyangkutkan minat, ketajaman, perhatian, konsentrasi, dan ketekunan. Siswa yang memiliki motivasi rendah dalam belajarnya menampakkan keengganan, cepat bosan dan berusaha menghindar dari kegiatan belajar.

Motivasi adalah motif-motif yang aktif dan berfungsi, karena adanya perangsang dari luar. Karena itu, metode berfungsi sebagai alat perangsang dari luar yang dapat membangkitkan belajar seseorang.

Dalam penggunaan metode terkadang guru harus menyesuaikan dengan kondisi dan suasana kelas. Jumlah siswa mempengaruhi penggunaan metode. Tujuan intruksional adalah pedoman yang mutlak dalam pemilihan metode. Dalam perumusan tujuan, guru perlu merumuskannya dengan jelas dan dapat diukur. Dengan begitu, mudahlah bagi guru menentukan metode yang bagaimana yang dipilih guna menunjang pencapaian tujuan yang telah dirumuskan tersebut.

Metode Make a Match adalah salah satu metode pembelajaran aktif yang penerapannya dapat memupuk kerja sama siswa dalam menjawab pertanyaan dengan mencocokkan kartu yang ada di tangan mereka. Dalam pelaksanaan metode make a match , guru terlebih dahulu menyiapkan bahan ajar, membuat rencana pelaksanaan pembelajaran, menyusun lembar instrumen observasi, membuat soal-soal yang akan diberikan kepada siswa berdasarkan kompetensi dasar yang dipelajari, dan mempersiapkan alat peraga untuk mengajar.

Langkah-langkah penerapan metode make a match yaitu: 1) guru menyiapkan beberapa kartu yang berisi 
beberapa konsep atau topik, satu bagian kartu soal dan bagian lainnya kartu jawaban, 2) setiap siswa mendapatkan sebuah kartu yang bertuliskan soal/jawaban, 3) tiap siswa memikirkan jawaban/soal dari kartu yang dipegang, 4) setiap siswa mencari pasangan kartu yang cocok dengan kartunya, 5) setiap siswa yang dapat mencocokkan kartunya sebelum batas waktu diberi poin, 6) jika siswa tidak dapat mencocokkan kartunya dengan kartu temannya (tidak dapat menemukan kartu soal atau kartu jawaban ) akan mendapatkan hukuman, yang telah disepakati bersama, 7) setelah satu babak, kartu dikocok lagi agar tiap siswa mendapat kartu yang berbeda dari sebelumnya, demikian seterusnya, 8) siswa juga bisa bergabung dengan 2 atau 3 siswa lainnya yang memegang kartu yang cocok, 9) guru bersama-sama dengan siswa membuat kesimpulan terhadap materi pelajaran.

Penerapan metode make a match dapat membangkitkan keingintahuan dan kerjasama di antara siswa serta mampu menciptakan suasana belajar aktif dan menyenangkan, dan materi pembelajaran yang disampaikan lebih menarik perhatian siswa, sehingga mampu meningkatkan motivasi belajar siswa.

Dengan demikian penggunaan metode Make a Match dapat meningkatkan motivasi belajar Fisika pada pokok bahasan mendeskripsikan gelombang bunyi. Dan setelah kegiatan belajar mengajar selesai diadakan tes untuk mengukur hasil belajar siswa.

Tujuan penelitian tindakan kelas ini adalah dengan penggunaan metode make a match dapat meningkatkan motivasi Belajar Fisika di Kelas XII SMA Negeri 1 Tebing Tinggi T.A 2014/2015 pada pokok bahasan mendeskripsikan gelombang bunyi.

\section{METODE PENELITIAN}

Penelitian ini dilaksanakan di SMA Negeri 1 Tebing Tinggi. Jenis penelitian ini adalah Penelitian Tindakan Kelas
(Classroom Action Research). Sesuai dengan jenis penelitian yang memiliki tahap-tahap yang berupa siklus prosedur penelitian yang terdiri dari dua siklus. Tiap siklus dilaksanakan sesuai dengan perubahan yang akan dicapai.

Subjek dalam penelitian ini adalah siswa Kelas XII IPA 4 SMA Negeri 1 Tebing Tinggi yang berjumlah 32 orang. Objek penelitian ini adalah tindakan untuk meningkatkan motivasi belajar Fisika.

Pelaksanaan penelitian tindakan kelas ini dilaksanakan selama dua siklus yang meliputi: perencanaan, tindakan, observasi dan refleksi. Secara rinci prosedur penelitian tindakan kelas ini akan diuraikan lagi, dimulai dari tahap perencanaan, tahap pelaksanan, tahap pengamatan dan ketahap refleksi. Prosedur penelitian tindakan kelas ini terdiri dari 2 siklus. Siklus I dan II masing-masing 2 kali pertemuan sehingga total pertemuan sebanyak 4 kali. Pada tahap perencanaan tindakan hal-hal yang direncanakan adalah sebagai berikut: menyusun rencana pembelajaran yang akan dilakukan, menyusun bahan ajar berupa Lembar Kerja Siswa (LKS) untuk setiap siswa dari setiap siklus pembelajaran, mempersiapkan instrumen penelitian dan lembar observasi untuk mengamati kegiatan (proses) belajar mengajar serta tes untuk mengukur hasil belajar siswa.

Akhir siklus I diadakan tes hasil belajar dan selanjutnya diadakan analisis dan refleksi. Pada siklus II, hasil refleksi pada siklus I akan dibuat suatu rekomendasi apakah tindakan pembelajaran itu masih perlu dilanjutkan atau tidak. Kalau dilanjutkan berarti ada perbaikan-perbaikan pada pembelajaran tersebut. Setelah diadakan perbaikanperbaikan, pada tahap awal siklus II ditujukan untuk menyelesaikan masalah yang belum tuntas di siklus I, setelah itu baru dilakukan tindakan pembelajaran kedua, dimana tindakan itu telah mengalami pembaharuan dari tindakan sebelumnya. Setelah tes diberikan kepada siswa dan diperoleh sejumlah informasi 
dari hasil tes, peneliti menganalisis kesulitan-kesulitan yang dialami siswa dalam menyelesaikan soal-soal fisika serta upaya penanggulangan yang diberikan. Hasil tes mengerjakan soal-soal fisika siswa dikatakan meningkat apabila ada pertambahan nilai rata-rata yang diperoleh siswa dari tes yang diberikan pada setiap siklusnya. Sedangkan untuk melihat hasil belajar yang berkembang dihitung rata-rata persentasenya dari masing-masing kemampuan siswa mengerjakan soal-soal fisika yang tercapai.

Kegiatan refleksi didasarkan pada data hasil observasi dan pekerjaan siswa pada LKS. Merinci dan menganalisis kondisi yang terjadi saat proses pembelajaran, terutama kekurangankekurangan dalam proses pembelajaran, sehingga pembelajaran yang dilakukan kurang berjalan lancar.

Bila hasil perbaikan yang diharapkan belum tercapai pada siklus I, maka tindakan masih perlu dilanjutkan pada siklus II. Pada siklus II diadakan perencanaan kembali dengan mengacu pada hasil refleksi pada siklus I. Siklus II.

Observasi yang dilakukan meliputi implementasi pada proses pembelajaran di kelas secara langsung.

Teknik analisis data yang dipakai dalam penelitian ini adalah analisis data, analisis hasil observasi dan reduksi data.

Analisis data dilakukan dengan perbandingan persentase guna menilai seberapa efektif motivasi siswa dengan menggunakan metode make a match dalam materi mendeskripsikan gelombang bunyi.

Analisis data hasil observasi dilakukan untuk mengetahui berhasil atau tidaknya tindakan yang dilakukan dalam penelitian ini. Hal ini dilihat dari seberapa keberhasilan yang dicapai dilihat dari motivasi belajar siswa secara individu dengan rumus : $\quad$ x 100 Keterangan:

$$
\begin{aligned}
& \mathrm{P}=\text { Angka motivasi belajar siswa } \\
& \mathrm{F}=\text { Jumlah skor subjek yang diamati } \\
& \mathrm{N}=\text { Jumlah skor maksimal keseluruhan } \\
& \text { subjek }
\end{aligned}
$$

Kriteria penilaian terhadap angka motivasi skor : 0 - 49 = kurang

$$
\begin{aligned}
& 50-69=\text { cukup } \\
& 70-85=\text { baik } \\
& 86-100=\text { sangat baik }
\end{aligned}
$$

Motivasi belajar siswa secara klasikal ditentukan dengan rumus:

$$
\begin{aligned}
\text { Kriteria skor : } & 0-49=\text { kurang } \\
& 50-69=\text { cukup } \\
& 70-85=\text { baik } \\
& 86-100=\text { sangat baik }
\end{aligned}
$$

Untuk mengetahui berhasil atau tidaknya tindakan yang dilakukan dalam penelitian ini, maka observasi untuk guru:

$$
\begin{gathered}
\text { Kriteria Skor : } 0-49=\text { kurang } \\
50-69=\text { cukup } \\
70-85=\text { baik } \\
86-100=\text { sangat baik }
\end{gathered}
$$

\section{HASIL PENELITIAN}

Ciri khusus penelitian tindakan kelas adalah adanya siklus-siklus yang merupakan suatu proses pemecahan masalah menuju proses pembelajaran yang lebih baik. Pada penelitian ini, peneliti menjalankan dua siklus. Pada awal kegiatan penelitian, peneliti memberikan pretest sebagai test awal untuk mengetahui tingkat pemahaman siswa terhadap materi pelajaran yang telah dipelajari dan diakhir pembelajaran akan diberi posttest untuk mengetahui perubahan yang terjadi. Untuk meningkatkan motivasi siswa dalam belajar perlu dilakukan pengelolaan kelas selama pembelajaran berlangsung. Sebelum melaksanakan pembelajaran di kelas, guru terlebih dahulu menyusun perencanaan dalam bentuk rencana pelaksanaan pembelajaran (RPP).

Berdasarkan hasil pengamatan observasi yang telah dilakukan guru pada siklus I dan siklus II, serta upaya-upaya yang dilakukan pada pembelajaran Fisika pada materi mendeskripsikan gelombang bunyi, dapat dilihat bahwa peningkatan motivasi belajar siswa melalui penggunaan 
metode make a match telah tercapai dengan baik, sehingga tidak dilanjutkan ke siklus berikutnya.

\section{PEMBAHASAN HASIL PENELITIAN}

Pada siklus I, tahap perencanaan membuat RPP yang sesuai dengan metode pembelajaran make a match dan membuat tes yang akan diberikan pada siswa pada saat kegiatan pembelajaran. Pada tahap ini, peneliti terlebih dahulu menjelaskan tentang metode pembelajaran make a match yang akan diterapkan di kelas kemudian menjelaskan materi pelajaran dengan singkat. Setelah itu peneliti memberikan pretes pada siswa untuk mengetahui sejauh mana tingkat pemahaman siswa tentang materi yang akan dipelajari. Dalam diskusi kelompok ini peneliti memotivasi siswa untuk mengumpulkan informasi yang sesuai, mencari penjelasan atau pengertian dari sumber lain dan mampu untuk memecahkan masalah dimana siswa dituntut untuk berpikir secara kritis dan kreatif. Setelah waktu yang disepakati peneliti mengumpulkan hasil karya atau hasil kerja dari masing-masing kelompok kemudian memilih salah satu kelompok untuk mempresentasikan hasil karya kelompoknya kepada kelompok lain dan kelompok lain diberi kesempatan untuk memberi tanggapan atau pertanyaan sesuai hasil diskusi kelompok mereka. Setelah semua kelompok mempresentasikan hasil diskusinya, peneliti menganalisis dan memberi evaluasi dari hasil diskusi kelompok dan mengevaluasi cara kerja kelompok siswa terhadap masalah yang ada kemudian memberikan penghargaan bagi kelompok yang kinerja kelompoknya efektif dan efisien. Peneliti mengarahkan setiap siswa supaya mengatur tempat duduknya dan kembali ke posisinya semula, setelah tertib peneliti memberi postes pada siswa untuk mengetahui sejauh mana perubahan yang terjadi pada siswa setelah penerapan metode pembelajaran make a match.
Saat melakukan diskusi kelompok masih ada siswa yang tidak melakukan aktivitas belajar, mereka hanya diam dan membiarkan temannya yang mempunyai kemampuan lebih mendominasi diskusi sehingga aktivitas siswa masih rendah karena mereka kurang aktif dan cenderung pasif selama kegiatan pembelajaran dan siswa hanya diam saja tanpa memberikan tanggapan atau pertanyaan saat guru menerangkan pembelajaran ataupun pada saat diskusi kelompok.

Pada siklus I pertemuan I, motivasi belajar siswa masih sangat rendah. Terdapat siswa yang mempunyai motivasi belajar yang baik, cukup dan kurang. Pada siklus I pertemuan I diperoleh data tidak ada siswa yang mempunyai motivasi belajar sangat baik, 3 orang siswa yang tergolong baik, 20 orang siswa yang tergolong cukup, dan 9 orang siswa yang tergolong kurang. Berdasarkan hasil pengamatan selama kegiatan pembelajaran berlangsung dapat dilihat bahwa aktivitas belajar masih kurang, dimana masih ada siswa yang hanya diam dan hanya sebagai pendengar saja. Terutama pada saat diskusi kelompok dimana siswa cenderung pasif dan membiarkan temannya yang berkemampuan lebih mendominasi dalam kelompok sedangkan siswa tersebut hanya diam dan mencatat hasil diskusi tanpa mau memberi masukan pada kelompoknya hal ini akan mempengaruhi hasil belajarnya. Berdasarkan masalah-masalah yang ditemukan selama diskusi I dijadikan sebagai bahan masukan bagi peneliti sebagai acuan untuk melakukan perbaikan dalam merancang tahap perencanaan pada siklus berikutnya.

Pada siklus I pertemuan II, motivasi belajar siswa masih rendah walaupun telah mengalami peningkatan dari pertemuan sebelumnya. Terdapat siswa yang mempunyai motivasi belajar siswa yang tergolong baik dan cukup. Pada siklus I pertemuan II diperoleh data bahwa tidak ada siswa yang memperoleh kriteria sangat baik, 10 orang siswa yang tergolong baik, 22 orang siswa yang tergolong 
cukup, dan tidak ada siswa yang tergolong kurang.

Pada siklus II pertemuan I diperoleh data bahwa 2 orang siswa yang tergolong sangat baik, 23 orang siswa tergolong baik, 7 orang siswa tergolong cukup dan tidak ada siswa yang tergolong kurang. Pada siklus II pertemuan II diperoleh data bahwa 4 orang siswa tergolong sangat baik, 26 orang tergolong baik, 2 orang tergolong cukup, dan tidak ada siswa yang tergolong kurang.

Pada pelaksanaan tindakan pada siklus II pertemuan II sudah mendapatkan hasil yang lebih baik mencapai kriteria yang diharapkan. Hal ini di buktikan dari nilai rata-rata yang diperoleh siswa pada siklus II pertemuan ke II, yaitu 78,7. Dengan tercapainya tingkat ketuntasan pada siklus II, maka proses belajar mengajar tidak lagi dilanjutkan pada siklus berikutnya,

Gambar 1. Perbandingan Tingkat Motivasi Belajar Siswa dari Siklus I Pertemuan I, Siklus I Pertemuan II , Siklus II Pertemuan I, dan Siklus II Pertemuan II

Berdasarkan Gambar 1, jelas sekali dapat dilihat bahwa jumlah siswa dalam motivasi belajar meningkat pada tiap siklus. Secara keseluruhan motivasi belajar yang mengalami perubahan dari siklus I pertemuan I, Siklus I pertemuan II, siklus II pertemuan I, siklus II, pertemuan II, Siswa yang mengalami peningkatan motivasi belajar pada kriteria baik dari siklus I pertemuan I ke siklus I pertemuan II adalah sebanyak 7 orang siswa. Perhitungan menggunakan data pada tabel. Siswa yang mengalami peningkatan motivasi belajar dari siklus I pertemuan II ke siklus II pertemuan I adalah sebanyak 13 orang siswa. Perhitungan dengan menggunakan data pada tabel. Siswa yang mengalami peningkatan motivasi belajar dari siklus II pertemuan I ke siklus II pertemuan II adalah sebanyak 3 orang siswa. Perhitungan dengan mnggunakan data pada tabel .

Berdasarkan hasil perhitungan di atas, tampak bahwa motivasi belajar siswa dari siklus I pertemuan I, siklus I pertemuan II, Siklus II pertemuan I ke siklus II pertemuan II semakin meningkat. Dengan demikian dapat disimpulkan bahwa terjadi peningkatan motivasi belajar melalui metode make a match di Kelas XII SMA Negeri 1 Tebing Tinggi.

\section{DAFTAR PUSTAKA}

Djamarah, S.B dan Zain, A. 2006. Strategi Belajar Mengajar. Jakarta : PT Rineka Cipta.

Lie, A. 2010. Cooperative Learning: Mempraktikkan Cooperative Learning di ruang-ruang Kelas. Jakarta : PT Grasindo.

Sardiman, A. M. 2009. Interaksi dan Motivasi Belajar Mengajar. Jakarta : Rajawali Pers.

Slameto, 2010. Belajar dan Faktor-Faktor yang Mempengaruhi. Jakarta : PT Rineka Cipta.

Uno, H. B. 2008. Teori Motivasi dan Pengukurannya: Analisis di Bidang Pendidikan. Jakarta: Bumi Aksara. 